\title{
The Manifesto \& the Hammer. A Review on How Contemporary Architecture Theories are being built
}

\author{
By Beatriz Villanueva Cajide
}

\begin{abstract}
When Panayotis Tournikiotis wrote Historiography of Modern Architecture in 1999 it started to be obvious the strategies the theorists of architecture have followed to present the words of the so-called pioneers of the Modernity as a kind of consistent discourse that eventually never existed. On top of that, if we see the original writings of those architects we will find that, in most cases, they use the format of a Manifesto probably influenced by the Avant-Garde artistic movements from the beginning or past century- to express those ideas. Based on Tournikiotis book and comparing his theory to the original Manifestoes it is clear how theorists of Modern architecture used these texts, that were just expressing immediate ideas on one particular matter, as small pieces in their own historical puzzle to build a theory capable of explaining the evolution of architecture since the Industrial Revolution. From the publication of the "gentle manifesto" Complexity and Contradiction in Architecture (Robert Venturi, 1966), according to some American authors like Charles Jencks the definition of an architect started to be dependent on his relationship with Modernity. In this way, Piano and Rogers are defined as Late-Modern architects because of their refusal to condemn Modernity (as Venturi and the Post-Moderns did) even though they considered themselves followers, such as Isozaki, Hertzberger or Foster. According to Piano and Roger's Manifesto of 1975, Declaration, could be interpreted as an attempt to make Modern architecture more contemporary by defending the idea of using the technique in a way the Pioneers never could, just because technology was not developed enough at the moment. At the same time other architects like Eisenman were somehow claiming a revolution from the basis of modernity, going beyond the question of style that Postmodernity had put on the table with its article-manifesto Post Functionalism (published by the magazine Oppositions in 1976), using two exhibitions of the MOMA to reinterpret the world according to the latest philosophical theories, introducing the idea of mixing disciplines to get a more contemporary (complex) result. In sight of this process the aim of this work is to show how this process has evolved in the latest years, in a way that nowadays the Manifestoes tend to be built to fit their place in the puzzle of the theory of architecture exactly and to secure the position of the architects in the line of argument of the contemporary theorist, necessary accomplice in this process.
\end{abstract}

\section{Introduction}

Manifesto comes from the latin word Manifestum, which is an adjective which means: "certain, evident". It turned into a noun when it started to be

\footnotetext{
${ }^{*}$ Lecturer, Prince Sultan University, Saudi Arabia.
} 
defined as "a written statement of the beliefs, aims, and policies of an organization, especially a political party."

As it can be understood from this definition, the Manifestoes will be always looking for a substantial change in the status quo. As it happens during the first era of the Manifesto, limited to Political themes, according to what Martin Puchner writes in his book Poetry of Revolution: Marx, Manifestos and Avant Gardes. ${ }^{2}$ Therefore the Declarations of Independence used by the new countries to get independence from the old big ones could be considered the first Manifestoes in History. That is how, by the Act of Abjuration, the Lower Countries declared the independence from the King of Spain (Felipe II) and became independent from Spain in 1581. This process was repeated for almost all the countries we know now using the Manifesto as a sort of Birth Certificate, like it happened with the Declaration of Independence of the United States of America from the United Kingdom in 1776. However, the paradigm of this first era was the Communist Manifesto, written by Marx and Engles in 1848: not only it proposed a Revolution but it came true with the Russian Revolution and even more; the Manifesto was used as a guideline to establish the basis for the Soviet Union after the Revolution. In this case, the relationship between cause and effect could not be clearer.

So if we look back to the first years of the Manifesto, it is obvious that it was used to promote significant changes in the existing situation that encouraged coetaneous societies to create a different world that, of course, is presented as the best possible. So it is mandatory to explain the changes to this society in a proper way for everybody to understand the benefits of joining the required Revolution. This necessity determines the format and the tone of the Manifesto, so it should be accompanied always, with the independence of the concrete topic addressed in a particular case, clear, direct and radical. These characteristics perfectly match the definition of the first Manifestoes in politics and they were also be the ones that attracted the Avant-Garde artist towards this format, they were responsible of starting what Martin Puchner describes as the second era, which was the Art Manifesto. At one point every single Avant-Garde movement seemed to need a Manifesto to be born. The Manifesto was also outlining the main facts that made the specific movement different from everything known since its birth. Probably due to the lack of freedom that separates Architecture from the rest of the arts, the Avant-Garde Manifestoes are not as important in our field as in other artistic disciplines, with some exceptions we will see later.

After these two periods, Puchner established the last one, in which we are now. An era full of contradictions that affect the format of the Manifesto, making it less radical, since the confrontation between the Manifestoes from the first and second eras are transforming it in a way that we cannot yet predict but, at least architectural-wise, that is what makes them fit in the argument

1. Cambridge dictionary online, http://bit.ly/2c2LT8V, [accessed May, 20th, 2015].

2. Martin Puchner, Poetry of Revolution: Marx, Manifestos and Avant Gardes (New York: Princenton University Press, 2005). 
lines with which some authors try to build the contemporary architectural theory.

\section{Brief History of the Manifesto in Architecture}

There are two main books dedicated to compiling the texts that are susceptible to be considered Manifestoes that have been written about architecture.

The first one, originally published in 1964 in Germay under the title of Programme und Manifeste zoo Architektur des 20, ${ }^{3}$ covers the Manifestoes written between 1903. Its author, Ulrich Conrads established the data for the first architectonic Manifesto [Programme, written this year by Herny van de Velde] until 1963, one year before its publication closing the book with We Demand, a collective Manifesto written for the exhibition Heimat, Deine Häuser was celebrated the same year in Stuttgart, Germany.

Continuing with Ulrich Conrad's work, Charles Jencks and Karl Kropf will publish in 1997 the book Theories and Manifestoes of contemporary architecture. ${ }^{4}$ They will complete Conrads' book finishing with the 13 propositions of Post-Modern Architecture, a Manifesto written by Charles Jencks in 1996.

According to these two main texts we can establish the following periods in the history of the Manifesto in architecture:

Looking for the New Architectural Language after the Industrial Revolution

The French and the Industrial Revolutions drew a completely new Europe. At the beginning of the 20th century architects whose education was separated from the Beaux Arts Academy had to confront, for the first time in History, a new rival profession: Engineering, seem to be in the middle of an identity crisis. The different theories that emerged as a result of this crisis are summarized in the Thesis and Antithesis of the Werkbund, ${ }^{5}$ a Manifesto from 1914 consisted of two antagonistic decalogues written by Herman Muthesius and Henry van de Velde, each one defending opposite strategies of design: the standardization and freedom of the designer, understood as artist, respectively.

\section{Breaking Boundaries: The Avant-gardes}

Although, as introduced before, the Avant-Garde movement was weaker in architecture than in other arts, there are some Manifestoes that deserved special

3. Ulrich Conrads, Programs and Manifestoes on 20th Century Architecture (Cambridge: MIT Press, 1970).

4. Charles Jencks and Karl Kropf, Theories and Manifestoes of contemporary Architecture (Chichester: Academy, 1997).

5. Hermann Muthesius and Henry van de Velde, Thesis and Antithesis of the Werkbund, written for the first exhibition and Conference of the Werbund (Cologne, Germany, 1914). 
consideration for their contribution to the development of the discipline, such as the Futurist Architecture, ${ }^{6}$ Manifesto $I^{7}$, Realistic Manifesto ${ }^{8}$ or Suprematist Manifesto. ${ }^{9}$ Utopian at their time, now their influence in opening new paths for the contemporary architecture is unquestionable.

\section{Socialist Manifesto}

During the first era of the Manifesto, Puchner identifies the political with the socialist Manifesto. As mentioned before, the paradigm of this era was the Communist Manifesto, so with the introduction of the communist ideas firstly through the Soviet Avant-Gardes, they were translated into architecture in texts like A program for Architecture, ${ }^{10}$ New ideas on architecture ${ }^{11}$ or Towards collective building. ${ }^{12}$ All of theese introduced new social concerns in the process of designing architecture.

\section{The Modernity and its Theoretical Frame}

With evident influences from the socialist Manifesto, the so-called "pioneers" started to write their own Manifestoes that, with different approaches but with the common basic ideas, were used to establish the Theoretical frame of the Modernity, as can be deduced from the Historiography of Architecture: ${ }^{13}$ Some examples are: Organic architecture, ${ }^{14}$ Towards a new architecture: guiding principles ${ }^{15}$ or Working Thesis. ${ }^{16}$

\section{The Roll of the Manifestos on Europe's Reconstruction after WWII}

During the interwar period Europe passed through an enormous process of reconstruction, dominated by the theories of the Modernity of urban planning. After experimenting life in these new cities, the ideas summarized in the Charte d'Athènes ${ }^{17}$ are questioned and new Manifestoes are formulated in search of more human cities: again searching for a new and better world. The creation of TEAM 10 is understood as an excision from the CIAM, so it can be said that it all started with the Doorn Manifesto. ${ }^{18}$

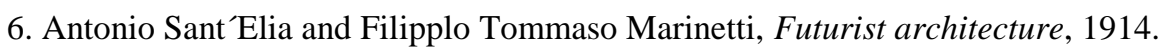

7. D'Stjl, Manifesto I, 1918. Later this dutch group will write other manifestoes such as: Creative Demands in 1922 and Manifesto V in 1923 among others.

8. Naum Gabo and Antoine Pevsner, Realistic Manifesto, 1920.

9. Kazimir Malévich, Suprematist Manifesto, 1924.

10. Bruno Taut, A program for Architecture, 1918.

11. Bruno Taut, Walter Gropius and Adolf Behne, New ideas on architecture, 1919.

12. Van Doesburg and Van Eesteren, Towards collective building, 1923.

13. Panayotis Tournikiotis, The Historiography of Modern Architecture (Cambridge: MIT Press, 1999).

14. Frank Lloyd Wright, Organic Architecture, 1910.

15. Le Corbusier, Towards a new architecture: guiding principles, 1920.

16. Ludwig Mies van der Rohe, Working thesis, 1923.

17. CIAM, Charter of Athens: tenets, 1933

18. TEAM 10, Doorn Manifesto, 1968. 
Change of Tone: The "Gentle Manifesto"

The conceptual crisis of the Modern movement opens the door for the birth of Post-Modernity that has a crucial peak in the Venturi's Complexity and Contradiction Manifesto. ${ }^{19}$

Technological Utopia: The 1960s

A new world can be created thanks to the new technologies: the faith in this statement established the intense period of the utopias in the second part of the past century with a proliferation of Manifestoes around 1960. Some examples that can be named are: The architect as world planner, ${ }^{20}$ The ten principles of space town planning, ${ }^{21}$ Universal Structure ${ }^{22}$ or No-plan. ${ }^{23}$

Contemporary Manifesto: Claiming for a Better World or just Pretending?

Venturi's "gentle Manifesto" open our minds to include, into this genre, texts that years ago didn't exist. A clear example of this is the Retroactive manifesto for Manhattan written by Koolhaas in $1978 .{ }^{24}$ Some other examples, as well as the strategies followed in the contemporary theory of architecture, will be analyzed below.

\section{Building a Contemporary Theoretical Frame}

It is highly convenient for the theory of architecture to be linked to the analysis of the buildings contemporary to it. This process was essential in the creation of the Modern Movement and, with different perspectives, all the theorist who studied the era explode its possibilities to the maximum extend. Sigfried Giedion and Reyner Banham, who are coincidentally two of the authors analyzed by Tournikiotis, ${ }^{25}$ are not an exception and it is more than probable that Charles Jencks learned his methods while studying with them in Harvard University and the Architectural Association respectively.

The clarity of the process in the case of the American theorist is so that it could be seen as a prototype or what is considered to be the building of the

19. Robert Venturi, Complexity and Contradiction in Architecture (New York: Museum of Modern Art Press, 1966).

20. Richard Buckminster Fuller, The architect as world planner, 1961.

21. Yona Friedman, The ten principles of space town planning, 1962.

22. Archigram, Universal structure, 1964.

23. Cedric Price, No-plan, 1969.

24. Rem Koolhaas, Delirious New York: a retroactive manifesto for Manhattan (Oxford University Press, 1978).

25. To illustrate the influence of the theories of the Historian of the Modernity, Panayotis Tournikiotis analyzed in The Historiography of Modern architecture nine essential books about Modernity written by nine historians: Sigfried Giedion and Reyner Banham together with Nikolaus Pevsner, Emil Kaufmann, Bruno Zevi, Leonardo Benevolo, Henry-Russell Hitchcock, Peter Collins, and Manfredo Tafuri. 
Theoretical frame for Contemporary architecture. Understanding, obviously, the term "building" as a conscious act that, as it has been explained before, imitates what happened with the analogue creation of the theory of Modern Architecture according to the process described by Tournikiotis, that Jencks knows perfectly because of his teachers and because of attending the last CIAM. $^{26}$

According to Charles Jencks, between Modernity and Post-Modernity will be two main movements: Late-Modernism and Neo-Modernism (also called New-Modernism). The differences between the two of them, as well as the evolution from Modernity will be used for Jencks to build the foundations of the Postmodernity, so this work will be focused on analyzing this particular movement and its evolution.

To make the classification of the three different movements that existed after Modernity, Jencks will enumerate 30 variables to analyze how they will evolve to get from one movement to the other, using architectonic examples to illustrate this development. Thus it would be easier for the reader to understand Post-Modernity as a logical evolution from the Modernity in an analogous process to the one that in 1939 followed Clement Greenberg and eventually allowed him to connect what he called the "American Expressionism" to the European Avant-Garde from the beginning of the 20th century: ${ }^{27}$ the Historical connection.

To understand his strategy we will see here some examples of the lines of Jencks' argument followed in his book The New Moderns. ${ }^{28}$

From Simplicity to Complex Simplicity-Oxymoron until Complexity Thought Disjunctive Complexity

One of the essential differences between Modernity and Post-Modernity is the introduction of the Complexity enunciated by Venturi in his "gentle Manifesto." 29 According to Jencks the transition since the simplicity of the Modernity to the Post-Modern complexity is possible thanks to the intermediate steps given by the Late and Neo-Moderns that he defined as "Complex Simplicity [Oxymoron]" and "Disjunctive Complexity" respectively. To demonstrate how simplicity became less and less important, Jencks will use several examples where he was able to find some signs of

26. Congrès International d'Architecture Moderne, (International Congresses of Modern Architecture) were a serious of encounters about Modern Architecture celebrated in different places of Europe between 1928 and 1959. Their influence in the expansion of the theories and ideas of the Modern Movement was tremendous as the main architects of the Modernity were active participants in those congresses. With Le Corbusier as one of the leaders the Charte d'Athènes (Athens Charter) was writing during one of these congresses. The end of the CIAM is the beginning of the TEAM 10.

27. Clement Greenberg, Avant-Garde and Kitsch, The Partisan Review, 1931: 34-49.

28. Charles Jencks, The New Moderns. From Late to Neo-Modernism (Chichester: Academy, 1997).

29. Robert Venturi, Complexity and Contradiction in Architecture (2nd edition) (New York: The Museum of Modern Art, 1977). 
change. So, he saw a clear example of an Oxymoron in the act of covering surfaces with opposites functions like the wall, roof or even stairs with grey concrete, like Roland Cote did in Alexanders' House in 1972, as well as he perceived a shift towards complexity in Eugene Kupper's Nilsson House from 1976, where, under the apparent simplicity we can find what Jencks described as a "complicated Post-Modern sequence." 30 From this complexity hidden behind an apparent simplicity typical of the Late-Moderns the Neo-Moderns, we jump to what Charles Jencks describes as "Disjunctive Complexity" where the interest for the context is clear. To illustrate it the author used Gehry's conversion of Edgemar Farms in Santa Monica into offices, shops and a small gallery. In this project Jencks sees vernacular motives mixed with Egyptian references and industrial objects, with an initial respect for the existing structures, introducing one of the main concerns of the Post-Modern architects: the context.

From being Anti-humour to Unintended humour-Malapropism until Get Go be Pro-Humour thanks to the Comic Destructive of the Neo-Mods

Following the same strategy, this time to explain the radical change in the relationship between humour and architecture from Modernity to PostModernity, Jencks establishes again the same two intermediate steps: the LateModerns "Unintended Humour" and the "Comic Destructive" of the NewModerns. The first one, exemplified with William Pereira's Transamerica building from 1968 appears "when the architect is in deadly earnest and trying hard to make the great architectural statement", 31 while the second comes directly from the act of dissection that he sees attached necessary to the Modern era. This is what Jencks believes, causes the defragmentation of the city and the use of contradiction in the architecture of the group SITE, example of what he called the "Comic Destructive". This fragmentation leads to the contradiction that, in his opinion, can be humorous. This is still far from the deliberate humour typical of Post-modernity but it is heading towards this.

The Change from being Anti-Ornament to be Pro-organic and Applied Ornaments

Rejecting Ornamentation was one of the first vindications of Modernity ${ }^{32}$ that change radically in Post-Modernity. As Charles Jencks explains in the book The New Moderns, this radical shift is possible thanks to the change of mind that supposed first the Late-Moderns Movement and just after the NewModerns'. The first ones transformed the structure and construction in the new ornament because, in Jenck's words, they expressed structure and construction vehemently, as Stirling did in the Leicester University Engineering building in

30. Jencks, The New Moderns. From Late to Neo-Modernism, 1997, 77.

31. Ibid, 90 .

32. Adolf Loos, "Ornament und Verbrechen [Ornament and Crime]," in Cahiers d'aujourd'hui, 5 (1913). 
1964, using the diagonal construction not only for functional reasons but also "to produce a giant 'dentil frieze'.",33 Going further, the Funder Factory building designed in 1987 by Coop Himmelblau, classified as a New-modern building, transforms the structure itself into an ornament by transforming it in something redundant and consequently not efficient. This means a clear break in the Modern conception of structure and, at some point, justifies the reintroduction of ornaments in Post-Modern architecture.

Machine Aesthetic-2nd Machine Aesthetic (Hyperbole) to Variable Mixed Aesthetic Thought Certain Traces of Memory

Although there are more examples on how the Late and New modern have facilitated the evolution from Modern to Post-Modern this is the last one that will be analyzed in the present paper mostly because its symbolism, as the machine aesthetic was first coined by Le Corbusier in his famous quote "a house is a machine for living in." ${ }^{34}$

After Modernity, the Late-Moderns reinterpreted this machine aesthetic by going further in the logic of the circulation, technologies and structure and starting what Jencks called the "2nd machine aesthetic" or "Hyperbole", as it happens at Gehry's house in Santa Monica (1978) where the architect exaggerates its "figures' to the point of an architecture hyperbole." These "figures" are referred to as elements that are over-dimensioned and highlighted with colors, such as cantilevered balconies, large windows and the like. As a result the house is more expressive and more complex although it is using a kind of industrial aesthetic that deserves the adjective of "Second Machine". Still this strategy is closed to modernity and very far from the "Variable Mixed Aesthetic", which is how Jencks defines the strategy of the Post-Modern regarding aesthetics. So the New Moderns are introducing the essential intermediate step with what Charles Jencks called "Traces of Memory" that consist basically in bringing to their architecture some symbolic elements to connect them with the past. That is what Peter Eisenman did in his social housing in Berlin in 1982 where he used an artificial excavation to introduce the idea of History, allowing the user to see the Eighteenth century foundations. For the New Moderns "excavation represents the past, the ground plane signifies the present and a new structure represents the future." ${ }^{35}$

Thanks to this simple strategy the step from the "Second Machine" aesthetic, was more complex than the Fist Machine one, but than the first one but still too attached to the industrial aesthetic, although closer to a more "Variable Aesthetics", as Jencks claims, thanks to the introduction of the history (past) in the buildings.

33. Jencks, The New Moderns. From Late to Neo-Modernism, 1997, 74.

34. Originally Une maison est une machine-à-habiter, in Vers une architecture [Towards an Architecture], first published in 1923.

35. Ibid, 280. 


\section{Contemporary $^{36}$ Manifesto}

Once the building analysis is done it seems clear that a tendency can be defined or, according to Jencks, two tendencies: Late and Neo-Modern, but still this is not enough to sketch out a proper theory. For this reason, this is the moment when the Manifestoes became important as instruments capable of building the necessary Theoretical frame.

As said before, in 1974 Charles Jencks, together with Karl Kropft wrote Theories and Manifestoes of Contemporary architecture with the intention of completing the previous Programs and Manifestos on 20 century architecture written ten years before by Ulrich Conrads. Although Jencks and Kropft seemed to respect Conrads' scheme, strictly introducing one Manifesto per chapter with a brief introduction before, they included an important difference in the index regarding the classification of the Manifestoes themselves. While Conrads was classifying them according to a clear and simple chronological order, Jencks and Kropf put ahead of this obvious order another one related more to their own ideas on how the contemporary theory of architecture evolved in those days. Therefore they divided the selected Manifestoes according to the following categories: Post-Modern, Post-Modern Ecology, Traditional, Late Modern and New Modern. The fact that some architects were apparently jumping from one category to another doesn't mean that all the authors could be part of the same movement, but it is caused by the creativity of the authors and other factors like the development of architects or architecture or because of "getting bored" as it happened with Philip Johnson according to Jencks and Kropf.

"The classification system we used reveals that a few architects jump between traditions. For instance, sometime after 1980, Leon Krier slid from Post-Modern to Traditional; Kenneth Frampton, usually attacking PostModernism, produced his highly influential essay supporting it - "Critical Regionalism" - in 1983, before jumping back to Late Modernism, with his writings on tectonics in 1989. From the seventies to the eighties, Robert Stern moved from Post-Modernism to Traditional, Christopher Alexander from Late to Post-Modernism, and so it goes." 37

Leaving the possibility of the weakness of this classification aside, the present work is focused on analyzing the connection between the Manifestoes selected for this book and the architectonic examples used by Jencks to illustrate the evolution from the Modern Movement in his book The New Moderns. The connection between the strategies outlined in this book (tendency) and the Manifestoes (theory) classified in the first one could draw the line of argumentation needed to establish the theory of the era between what Jencks describes as the two main movements of the 20th century: Modernity and Post-Modernity.

36. In the present article the term "contemporary" is used to describe all those manifests outlined since the end of the great utopias of the sixties until today.

37. Charles Jencks and Karl Kropf, Karl, Theories and Manifestoes of contemporary architecture (Chichester, Academy, 1997), 8-9. 
Going back to the previous section we can resume the main changes from Modernity to Post-Modernity in which the Late and New-Moderns effectively influenced accordingly to the following categories:

\section{Complexity}

Introduction of the complex forms: the rational shapes are developed towards more articulated ones, although at the beginning still respecting a certain idea of simplicity. The creator of the new modernity, Peter Eisenman ${ }^{38}$ explains the new process of design in his previous manifesto Cardboard Architecture from 1972:

"Cardboard is used to shift the focus from our existing conception of form in an esthetic and functional context to a consideration of form as a marking or notational system. The use of cardboard attempts to distinguish an aspect of these forms which are designed to act as a signal or a message and, at the same time the representation of them as a message." ${ }^{39}$

\section{Humour}

Humour is essential as it is able to improve the communication between common people, one of the biggest problems of Modernity. The necessary defragmentation to achieve this humorous effect is described in the catalogue for the exhibition Deconstructivist Architecture written as a Manifesto with the same name by one of the curators of the MOMA exhibition: Mark Wigley.

"This disturbance does not result from external violence. It is not a fracturing slicing, fragmentation or piercing. When disturbing a form from the outside in these ways doesn't mean you have to threaten that form, only to damage it. The damage produces a decorative effect, an aesthetic of danger, an almost picturesque representation of peril - but not a tangible threat. Instead, deconstructivist architecture disturbs figures from within..."

\section{Context}

The respect for the context to break the Machine Aesthetic is one of the most characteristic elements of Post-Modern architecture. This change regarding the relationship with History is clear at the end of Philip Johnson's Manifesto The seven Crutches of Modern Architecture:

"I am traditionalist. I believe in History. By tradition, I mean the carrying out, in freedom, the development of a certain basic approach to architecture

38. According to what Charles Jencks wrote in his book The New Moderns. From Late to Neo-Modernism, Peter Eisenman's article Post-Functionalism [Oppositions 6, Fall 1976] represents the birth of the New Mods.

39. Peter Eisenman, "Cardboard Architecture: House I," in Five Architects (New York: Witttenborn, 1972), p.16.

40. Mark Wigley, Deconstrutivist Architecture (New York: MOMA, 1988). 
which we find upon beginning our work here. I do not believe in perpetual revolution in architecture. I do not strive for originality..."

\section{Conclusion: Manifesto as a Hammer}

Charles Jencks wrote The language of Post-Modern architecture, ${ }^{42}$ one of his major publications, in the form of a Manifesto following the lessons of Giedion, in order to give a historical legitimacy to Post-Modernity, the movement he created. It is not a coincidence that he decided to use this format as other Avant-Garde artists did before, because he declared the death of Modernity and the birth of the new movement, Post-Modernity, that will be successful where the other failed, especially in the communication with the public, a crucial point for the Post-Modern historiography. ${ }^{43}$

It also shows the importance that Manifestoes have for the author as a way to communicate better. The same idea is clear when it comes to connect theory and practice or, what would be the same, Manifestoes and building analysis. As Jencks may have noticed, this will be especially effective when the Manifesto and the building have the same author so theory and tendency are clearly connected and argument lines are absolutely consistent.

But contemporary architecture is too close to be analyzed properly. Although authors like Charles Jencks insisted in making both theory (Manifestoes) and architectonic elements (building analysis) to appear as consistent the truth is that looking beyond the selected texts and buildings the reality of contemporary architecture is still disperse, disorganized and impossible to label at the moment. Manifestoes, as hammers, are effective building tools but they have to be preserved carefully to be interpreted with the proper distance and read with an honest, impartial and clear view.

\section{Bibliography}

Archigram. Universal structure, 1964.

Buckminster Fuller, Richard. The architect as world planner. 1961.

Cambridge dictionary online. http://bit.ly/2c2LT8V. [Accessed May, 20 ${ }^{\text {th }}, 2015$ ].

CIAM. Charter of Athens: tenets. 1933.

Conrads, Ulrich, 1973. Programs and Manifestoes on 20th century architecture.

Cambridge, Massachusetts: MIT Press, 1970.

D’Stjl. Manifesto I, 1918.

Eisenman, Peter. "Cardboard Architecture: House I." In Five Architects. New York: Witttenborn, 1972: 16.

Eisenman, Peter. "Post-Functionalism.” In Oppositions, 6. 1976.

Friedman, Yona. The ten principles of space town planning. 1962.

41. Philip Johnson, The seven crutches of Modern Architecture, 1954.

42. Charles Jencks, The language of Post-Modern Architecture (New York: Rizzoli, 1977).

43. Elie Hadad, "Charles Jencks and the historiography of Post-Modernism," published in The Journal of Architecture 14, no. 4. 
Gabo, Naum and Antoine Pevsner. Realistic Manifesto. 1920.

Greenberg, Clement. Avant-Garde and Kitsch, The Partisan Review. 1931: 34-49.

Hadad, Elie. "Charles Jencks and the historiography of Post-Modernism." Published in The Journal of Architecture 14, No. 4.

Jencks, Charles. The language of Post-Modern architecture. New York: Rizzoli, 1977.

Jencks, Charles. The New Moderns. From Late to Neo-Modernism. Chichester: Academy, 1997.

Jencks, Charles and Karl Kropf. Theories and Manifestoes of contemporary architecture. Chichester: Academy, 1997.

Johnson, Philip. The seven crutches of Modern Architecture. 1954.

Koolhaas, Rem. Delirious New York: a retroactive manifesto for Manhattan. Oxford University Press, 1978.

Le Corbusier. Towards a new architecture: guiding principles. 1920.

Loos, Adolf. "Ornament und Verbrechen [Ornament and Crime]." In Cahiers d'aujourd'hui, 5. 1913.

Malévich, Kazimir. Suprematist Manifesto. 1924.

Mies van der Rohe, Ludwig. Working thesis. 1923.

Muthesius, Hermann and van de Velde, Henry. Thesis and Antithesis of the Werkbund. Written for the first exhibition and Conference of the Werbund. Cologne, Germany, 1914.

Price, Cedric. No-plan. 1969.

Puchner, Martin. Poetry of Revolution: Marx, Manifestos and Avant Gardes. New York: Princenton University Press, 2005.

Sant ${ }^{\prime} E l i a$, Antonio and Marinetti, Filipplo Tommaso. Futurist architecture. 1914.

Taut, Bruno. A program for Architecture. 1918.

Taut, Bruno. Gropius, Walter and Behne, Adolf. New ideas on architecture. 1919.

TEAM 10. Doorn Manifesto. 1968.

Tournikiotis, Panayotis. The Historiography of Modern Architecture. Cambridge: MIT Press, 1999.

Van Doesburg and Van Eesteren. Towards collective building. 1923.

Venturi, Robert. Complexity and Contradiction in Architecture. New York: Museum of Modern Art Press, 1966.

Venturi, Robert. Complexity and Contradiction in Architecture ( $2^{\text {nd }}$ edition). New York: Museum of Modern Art Press, 1977.

Wigley, Mark. Deconstrutivist Architecture. New York: MOMA, 1988.

Wright, Frank Lloyd. Organic Architecture. 1910.

Venturi, Robert, Complexity and Contradiction in Architecture, Museum of Modern Art Press, New York, 1977 (2nd. edition).

Wigley, Mark, Deconstrutivist Architecture, MOMA, New York, 1988.

Wright, Frank Lloyd, Organic Architecture, 1910. 